\title{
Penyuluhan Budidaya Lele dan Azolla untuk Warga Pengajian MTA Banjarsari, Surakarta
}

\author{
Sudadi* dan Suryono \\ Program Studi Ilmu Tanah, Fakultas Pertanian, Universitas Sebelas Maret, Surakarta \\ *Corresponding Author: sudadi62@staff.uns.ac.id
}

\begin{abstract}
ABSTRAK
Program PKM ini bekerjasama dengan dua mitra, yaitu (1) MTA Cabang Banjarsari Surakarta, dan (2) Peternakan Lele "Dwipangga". Mitra 1 berlokasi di dukuh Gebang, Kelurahan Banjarsari, Kecamatan Banjarsari, Kota Surakarta. Mitra 1 adalah lembaga dakwah islamiyah non profit sedangkan bidang usaha yang dikembangkan oleh mitra 2 adalah peternakan lele. Permintaan konsumen terhadap ikan lele di Surakarta dan sekitarnya per hari sangat tinggi, belum mampu dipenuhi oleh mitra usaha tersebut. Permasalahan yang dihadapi oleh mitra 1 adalah masih adanya warga binaan pengajian yang kondisi ekonominya kurang mampu, kurang produktif. Permasalahan yang dihadapi mitra 2 adalah biaya yang tinggi untuk menyediakan pakan ikan lele yang berkualitas. Kebutuhan pakan lele per minggu mencapai 200-250 kg, dengan harga pakan rata-rata Rp. 8.300,- per kg. Oleh karena itu diperlukan penyediaan pakan alternatif, seperti azolla yang memiliki nilai gizi tinggi dan cepat perkembangbiakannya. Azolla adalah satu-satunya genus paku air yang mengapung. Selain dapat digunakan sebagai pupuk hijau, Azolla dimanfaatkan untuk pakan ikan karena mengandung nutrisi tinggi dan mengapung yang dapat langsung dimakan ikan ataupun dibuat pelet. Tujuan dari kegiatan ini adalah untuk mengatasi permasalahan utama yang dihadapi Mitra 1 yaitu membuka peluang peningkatan ekonomi keluarga dan Mitra 2 yaitu mengatasi mahalnya pakan lele dengan menggunakan Azolla sebagai pakan substitusi yang dibudidayakan bersama lele. Metode yang digunakan dalam kegiatan ini adalah memberi bimbingan dan praktek langsung kepada mitra tentang budidaya lele bersama azolla, bantuan pembuatan kolam, bibit azolla, bibit dan pakan lele. Hasil kegiatan ini adalah meningkatnya pengetahuan dan ketrampilan mitra 1 dalam budidaya lele bersama azolla dan TTG budidaya sistem ganda azolla-lele yang telah diterapkan oleh mitra 2.
\end{abstract}

Kata kunci : Azolla, pakan substitusi lele, peningkatan ekonomi, ternak lele

\section{ABSTRACT}

This Community Service Program (CSP) is in collaboration with two partners, namely (1) MTA Banjarsari Branch, Surakarta and (2) Dwipangga Catfish Farm. First partner is located in Gebang, Banjarsari District, Surakarta. First partner is a non profit Islamic preaching organization and the second partner is catfish farming bussiness sector. Every day, demanding of catfish in Surakarta and arrounding areas in it is very high but the partner unable to provide. The problem faced by partner 1 is that there are still residents who are underprivileged, less productive. The problem faced by partner 2 is the high cost of providing quality catfish feed. he need for catfish feed per week reaches 200-250 kg, with an average feed price of $R p .8,300$ per $\mathrm{kg}$. Therefore it is necessary to provide alternative feeds, such as azolla which has high nutritional value and is fast in breeding. Azolla is the only genus of floating nails. Besides being able to be used as green fertilizer, Azolla is used for fish feed because it contains high nutrients and floats that can be directly eaten by fish or made pellets. The purpose of this activity is to overcome the main problem faced by Partner 1, which is to open opportunities for increasing the family's economy, and Partner 2, which is to overcome the high cost of catfish feed by using Azolla as a substitute feed that is cultivated with catfish. The method used in this activity is to provide guidance and practice directly to partners about catfish cultivation with azolla, assistance in making ponds, azolla seeds, seedlings and catfish feed. The results of this activity are increased knowledge and skills of partner 1 in catfish cultivation with azolla and appropriate technology in the azolla -catfish dual system cultivation that have been applied by partners.

Keywords: Azolla, catfish, catfish feed substitution, economic improvement 


\section{PENDAHULUAN}

Program PKM ini bekerjasama dengan dua mitra, yaitu: (1) MTA Cabang Banjarsari Surakarta, dan (2) Peternakan Lele "Dwipangga". Mitra 1 berlokasi di Dukuh Gebang, Kelurahan Banjarsari (d/h Kadipiro, Kecamatan Banjarsari, Kota Surakarta, dengan jarak tempuh sekitar $\pm 3,5 \mathrm{~km}$ dari Fakultas Pertanian UNS. Mitra 1 adalah lembaga dakwah Islamiah non profit yang membina mental spiritual warga masyarakat di sekitarnya melalui kegiatan pengajian rutin. Disamping itu MTA Cabang Banjarsari juga berusaha mendorong agar kehidupan ekonomi warganya maju sehingga dapat hidup lebih sejahtera. Berbagai upaya telah ditempuh, seperti mendatangkan praktisi budidaya semut ngangkrang dan mengajak warganya untuk belajar usaha peternakan lele. Sebagian besar warga tergolong ekonomi menengah ke bawah dengan mata pencaharian sebagian besar sebagai buruh (bangunan, pabrik, industri kecil), beberapa orang sebagai PNS dan wirausaha kecil-mikro. Rata-rata warga MTA Cabang Banjarsari memiliki etos kerja yang tinggi, jujur dan ulet. Kondisi ekonomi warga tersebut perlu mendapat perhatian untuk ditingkatkan, salah satunya dengan memperkenalkan usaha ternak lele. Agar biaya usaha ternak lele tidak terlalu mahal, maka perlu dicarikan jalan keluar yaitu dengan memadukannya bersama budidaya azolla. Dari hasil penelitian kami dan praktek yang telah dijalankan oleh Mitra 2, budidaya lele bersama azolla dapat menekan biaya pakan hingga $20 \%$. Mitra 2 berlokasi di Dukuh Gunung Sari, Desa Ngringo, Palur, Kecamatan Jaten, Kabupaten Karanganyar, Jawa Tengah. Bidang usaha yang dikembangkan oleh mitra 2 tersebut adalah peternakan lele. Mitra 2 sudah sangat berpengalaman dalam usaha peternakan lele, termasuk dalam budidaya lele menggunakan azolla sehingga dapat menjadi pembimbing mitra 1 dalam memulai usaha ternak lele (Sudadi, 2017). Permintaan konsumen terhadap ikan lele di Surakarta dan sekitarnya per hari sangat tinggi, dan belum mampu dipenuhi oleh peternak lokal Surakarta dan sekitarnya. Melalui usaha kemitraan antara mitra 1 , mitra 2 dan tim pelaksana dalam kegiatan pengabdian ini diharapkan dapat mendorong terbukanya peluang usaha bagi sebagian warga MTA Cabang Banjarsari, Surakarta sehingga dapat meningkatkan ekonominya.
Kondisi mitra usaha. Kondisi mitra MTA Cabang Banjarsari, Surakarta MTA Cabang Banjarsari Surakarta bukan lembaga yang bergerak dalam bidang usaha ekonomi, tetapi merupakan lembaga dakwah Islamiah non profit, yang bergerak dalam pembinaan keagamaan Islam para warganya. Namun, karena pelaksanaan agama tidak hanya sekedar menjalankan ibadah saja, tetapi juga dalam membentuk keluarga yang sehat secara ekonomi, maka pengurus MTA Cabang Banjarsari sangat mendorong warganya untuk senantiasa meningkatkan kondisi ekonominya. Saat ini jumlah warga MTA Cabang Banjarsari ada sekitar 300 orang, teridiri dari bapak-bapak, ibu-ibu dan remaja. Sebagian besar memiliki kondisi ekonomi menengah ke bawah. MTA Cabang Banjarsari belum memiliki suatu bentuk usaha yang dapat membantu meningkatkan ekonomi warganya. Beberapa kali telah pernah mendatangkan praktisi usaha berbagai bidang, namun belum memberikan hasil yang memuaskan. Beberapa warga ada yang memelihara lele namun tidak diusahakan sebagai usaha ekonomi. Melihat etos kerja, keuletan dan kejujurannya warga MTA Cabang Banjarsari memiliki potensi untuk menjadi wirausaha khususnya ternak lele.

Kondisi mitra 2 usaha Peternakan Lele 'Dwipangga'. Peternakan Lele 'Dwipangga' merupakan usaha mikro milik Aren Dwipa Pangastuti. Lokasi kegiatan usaha ini berada di Dukuh Gunung Sari, Desa Ngringo, Kecamatan Jaten, Kabupaten Karanganyar. Manajemen usaha yang dikembangkan berdasarkan manajemen usaha keluarga. Dwipangga mempekerjakan 2 orang tenaga kerja. Kegiatan usaha yang dikembangkan menempati areal seluas sekitar $400 \mathrm{~m}^{2}$, dengan jenis usaha peternakan lele.

Budidaya ikan lele di lokasi mitra dilakukan pada 18 buah kolam, dan setiap kolam rata-rata berisi $2.000-2.500$ ekor lele. Pada saat panen lele baru dapat dilakukan setiap 1 minggu sekali, dengan rata-rata produksi per kolam sekitar $200-225 \mathrm{~kg}$, dengan rata-rata harga lele Rp. 12.000,- per kg. Kapasitas produksi lele saat ini juga belum mampu menyediakan permintaan lele yang tinggi untuk melayani konsumen di Karanganyar dan sekitarnya. Di daerah lain seperti daerah Yogyakarta membutuhkan sebanyak 12-16 ton ikan lele konsumsi tiap hari. Hal ini dikarenakan banyaknya warung-warung pecel lele yang dibuka di kota pelajar ini setiap malam. (Anonim, 2009). 
Di sekitar kolam lele masih terdapat lahan yang kosong dan belum termanfaatkan, sehingga direncanakan untuk lokasi pengembangan pembuatan pakan lele. Pakan lele akan memanfaatkan Azolla yang ditanam/ ditaburkan pada kolam yang lelenya masih kecil yang dapat berfungsi sebagai pakan lele yang masih kecil (pertumbuhan Azolla lebih cepat dibandingkan yang dimakan lele). Kelebihan dari yang dimakan lele kecil dapat digunakan sebagai pakan langsung lele yang besar ataupun sebagai campuran pembuatan pelet dari kotoran puyuh. Pembuatan pakan lele tersebut dapat mengurangi biaya produksi ternak lele yang sangat menguntungkan karena bisa menekan biaya pakan 20-40\% (Anonim, 2020c; Sudadi dan Suryono, 2016). Azolla merupakan paku-pakuan air yang berasosiasi dengan ganggang - hijau biru (blue-green algae) Anabaena azollae yang dapat menambat nitrogen dari udara sehingga asosiasi ini memiliki kandar $\mathrm{N}$ yang tinggi, sangat baik untuk pakan ikan termasuk lele (Khan, 1988). Menurut Anonim (2020b) azolla merupakan alami yang sangat baik untuk lele karena mengandung protein $31,25 \%, 7,5 \%$ lemak, karbohidrat sebanyak 6,5\%, gula terlarut
$3,5 \%$ dan serat kasar $13 \%$. Penggunaan azolla sebagai pakan bisa dalam bentuk segar, atau dibuat pelet setelah ditepungkan (Anonim, 2020a; 2020b).

Permasalahan yang dihadapi mitra 2 adalah biaya yang tinggi untuk menyediakan pakan ikan lele yang berkualitas. Kebutuhan pakan lele per minggu mencapai $200-250 \mathrm{~kg}$, dengan harga pakan rata-rata Rp. 8.300,- per kg. Oleh karena itu diperlukan penyediaan pakan alternatif, seperti pelet dari kotoran puyuh yang dapat diproduksi dengan menggunakan kotoran ternak puyuh dan Azolla yang dipelihara pada kolam yang lelenya masih kecil dan pemanfaatan limbah bulu ayam sebagai bahan pembuatan pelet (Suwarto, 2017).

Pemanfaatan Azolla yang dibudidayakan di kolam lele yang masih kecil dan pemanfaatan kotoran ternak puyuh untuk bahan pembuatan pelet merupakan wujud nyata dari penerapan keterpaduan antara peternakan puyuh, lele dan Azolla. Dengan demikian selain akan memberikan peningkatan penghasilan bagi peternak, maka juga akan meningkatkan kualitas produk lele organik, pengurangan biaya produksi, dan tidak mencemari lingkungan.

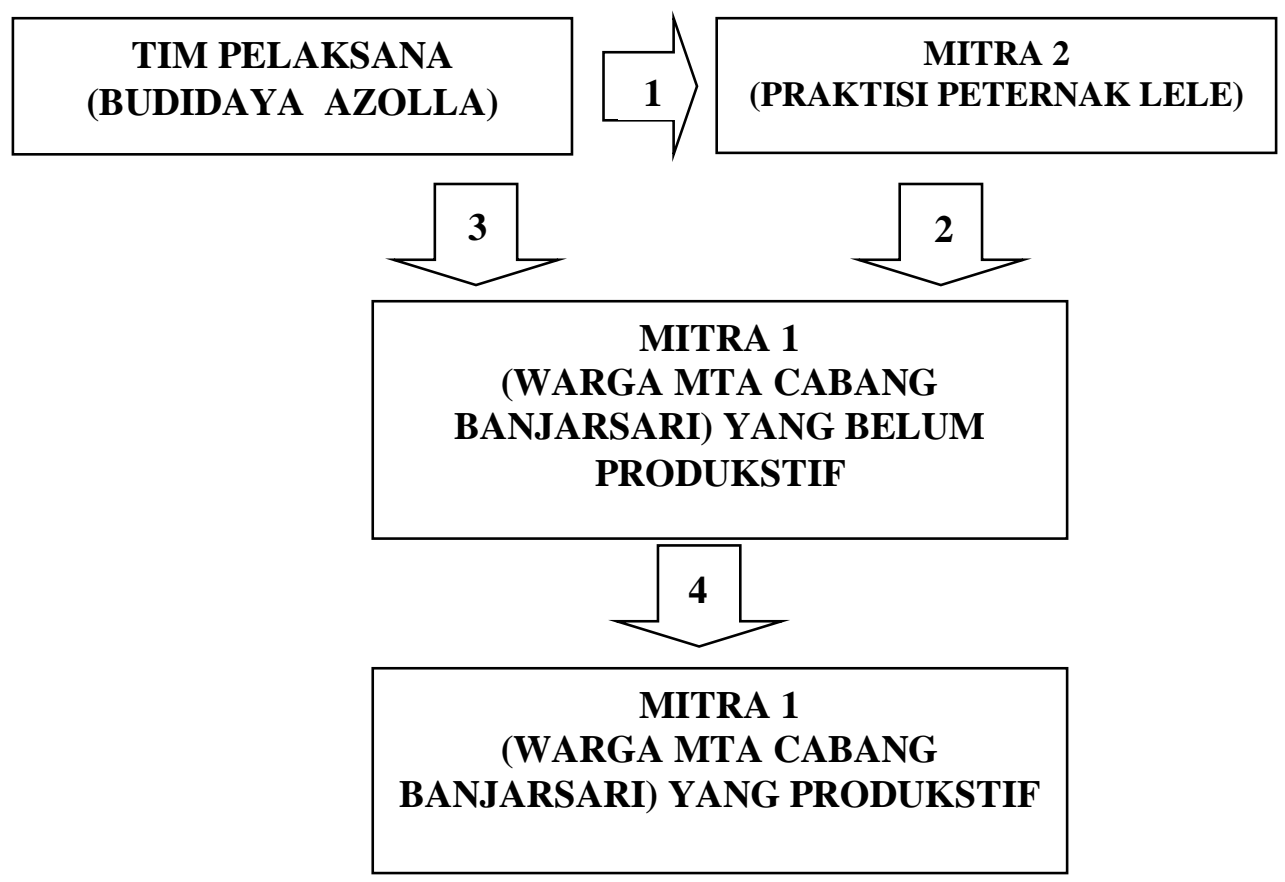

Keterangan :

1. Tim Pelaksana memberi alih teknologi budidaya azolla ke mitra 2

2. Tim Pelaksana bersama Mitra 2 memberi pelatihan teknis budidaya lele dan azolla ke mitra 1

3. Tim pelaksana memfasilitasi dalam bentuk bantuan bahan dan alat

4. Mitra 1 yang tidak produktif menjadi produktif sbg peternak lele

Gambar 1. Peta Jalan Pengabdian Kepada Masyarakat 


\section{METODE}

Metode yang digunakan untuk mengatasi permasalahan utama yang dihadapai mitra (1) adalah penyuluhan dan pelatihan usaha ternak lele bersama azolla. Dari hasil penelitian Sudadi dan Suryono, budidaya terpadu lele dan azolla dapat menurunkan biaya pakan hingga $20 \%$ (Sudadi \& Suryono, 2016). Kegiatan akan difasilitasi dengan memberikan bantuan berupa bahan dan alat untuk budidaya terpadu lele azolla tersebut.

Metode yang ditawarkan untuk mengatasi permasalahan yang dihadapi mitra (2) adalah bimbingan budidaya terpadu lele-azolla yang dipelihara pada kolam yang lelenya masih kecil. Karena lele yang masih kecil kecepatan makannya lebih rendah dibanding kecepatan pertumbuhan azolla maka akan ada kelebihan azolla di kolam lele yang masih kecil tersebut. Kelebihan azolla ini diambil untuk diberikan pada kolam lele yang sudah besar yang kecepatan makannya lebih tinggi dibanding kecepatan pertumbuhan azolla sehingga azolla yang diberikan pada kolam lele yang sesudah besar biasanya selalu habis dimakan lele. Dengan memberikan azolla dari kolam lele yang masih kecil ke kolam lele yang sudah besar maka akan mengurangi jumlah pakan untuk lele yang sudah besar sehingga hal ini akan mengurangi biaya pakan lele secara keseluruhan. Pakan yang diberikan berupa pelet dengan kandungan protein berkisar antara 26-28\%. Pemberian pakan ini dilakukan secara berkala dengan dosis
3-6 \% dari bobot total ikan dan frekuensi pemberiannya sebanyak $4 \quad-5$ kali sehari.Kandungan nutrisi pakan lele yang baik adalah protein $>30 \%$, lemak $4-16 \%$, karbohidrat $15-20 \%$, mineral dan vitamin (Alamtani, 2013). Dalam hal ini mitra memberikan pakan dengan frekuensi 3 kali yaitu pagi, siang dan sore.

Partisipasi mitra dalam pelaksanakan program PKM ini adalah : penyediaan tempat pelatihan budidaya lele dan azolla, lahan untuk membuat kolam lele dan penyediaan sumberdaya manusia sebagi subyek untuk dilatih pada kegiatan program ini.Hal ini sudah dilakukan berdasarkan pengalaman yang cukup panjang dalam budidaya lele dan hasilnya cukup baik.

\section{HASIL DAN PEMBAHASAN}

Kegiatan telah dilaksanakan sesuai rencana yaitu memberi bimbingan teknis cara budidaya double sistem (budidaya ganda) leleazolla kepada mitra 2 dan bersama mitra 2 memberikan penyuluhan dan pelatihan budidaya lele- azolla kepada mitra 1. Dari hasil bimbingan teknis, mitra 2 dapat menekan biaya pakan lele sebesar 20\% dengan menerapkan budidaya ganda lele-azolla. Hal ini karena azolla merupakan alternatif pakan yang memiliki nilai gizi tinggi terutama kandungan nitrogen yang tinggi.

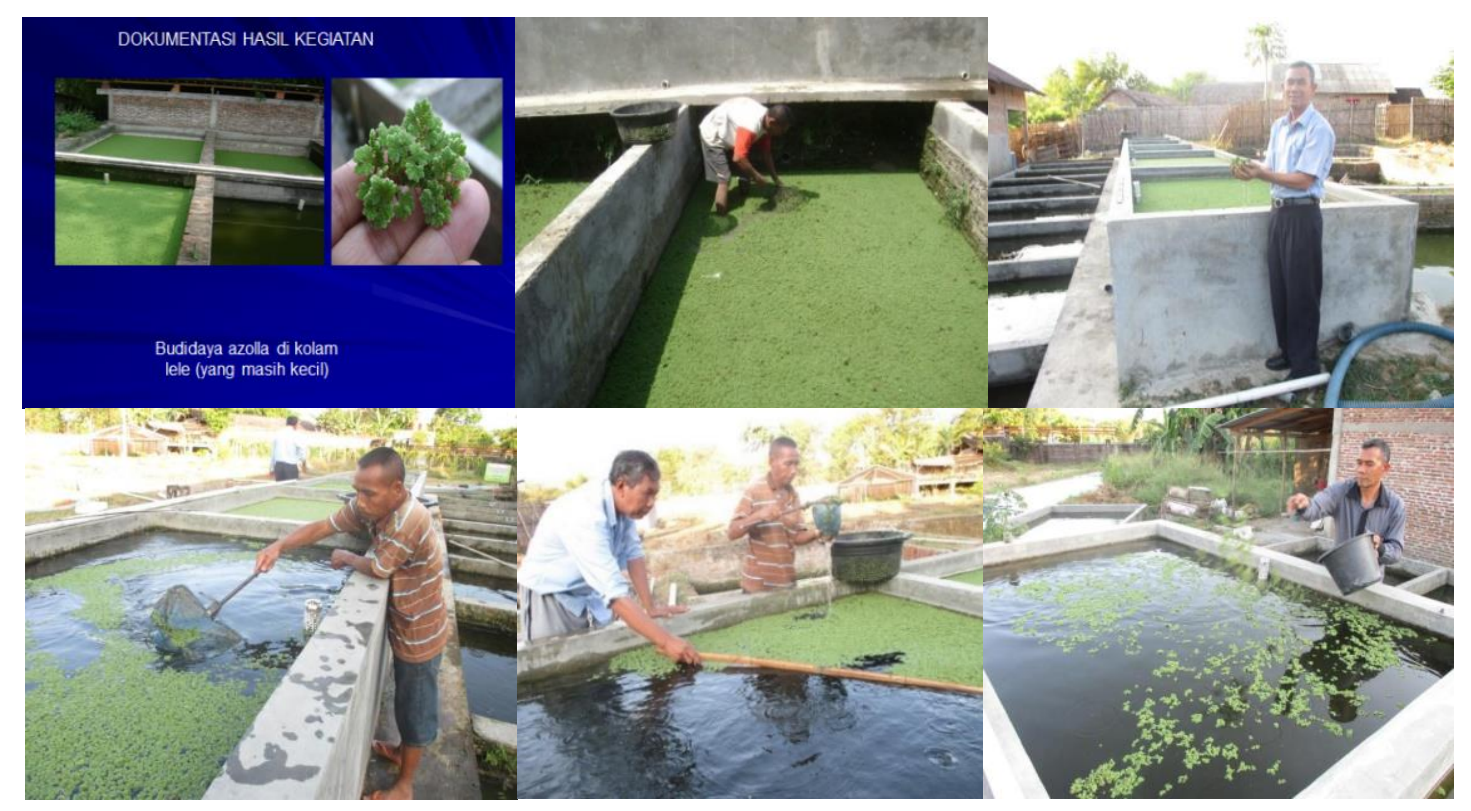

Gambar 2. Kegiatan pelaksanaan budidaya azolla dan lele di lokasi Mitra 2 
Penyuluhan kepada warga pengajian MTA Cabang Banjarsari telah dilaksanakan pada Ahad malam tanggal 29 September 2019 sesuai jadwal pengajian di Majelis MTA Cabang Banjarsari dan pelatihan di lokasi budidaya lele dari mitra 2 di Dusun Gunung Wujil, Palur, Jaten, Karanganyar. Kegiatan yang telah dilaksanakan dapat dikatakan memberikan hasil yang baik, yang ditunjukkan oleh (1) materi kegiatan dapat diterima oleh kedua mitra, (2) materi yang telah diterima dipraktikkan oleh mitra untuk mengatasi masalahnya, dan (3) tanggapan mitra terhadap materi kegiatan cukup baik dengan indikasi kehadiran mitra dalam mengikuti kegiatan yang dilaksanakan.

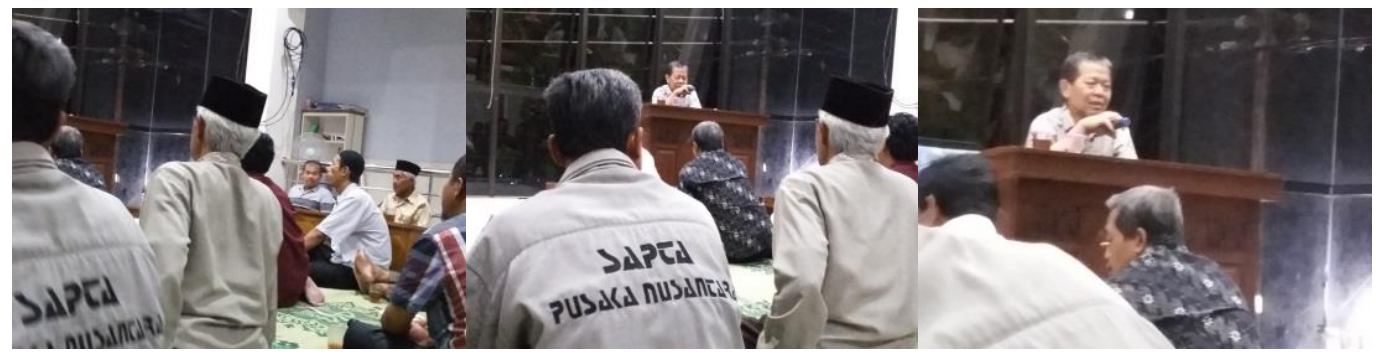

Gambar 3. Kegiatan penyuluhan di Majelis MTA Cab. Banjarsari. Ketua Cabang sedang memberikan arahan.

\section{KESIMPULAN}

Dari kegiatan yang telah dilaksanakan dapat disimpulkan bahwa mitra 1 dan 2 merasakan manfaat dari adanya kegiatan ini. Mitra 1 merasakan tambahnya pengetahuan dan ketrampilan dalam usaha kreatif untuk membuka lapngan usaha. Mitra 2 merasakan manfaatnya karena dengan budidaya sistem ganda azolla lele dapat menekan biaya pakan lele sebesar $20 \%$ sehingga usaha budidaya lelenya lebih menguntungkan. Kegiatan PKM cukup berhasil dengan diterimanya materi kegiatan dan dilaksanakan oleh mitra dalam usaha untuk mengatasi masalahnya.

\section{UCAPAN TERIMA KASIH}

Penulis mengucapkan terima kasih yang sebesar-besarnya kepada Ketua LPPM UNS dan jajarannya, dekan dan jajarannya, CV Dwipangga, Ketua Cabang MTA Banjarsari, Surakarta atas kerjasama dan segala bantuannya dalam kegiatan PKM ini.

\section{DAFTAR PUSTAKA}

Alamtani. 2013. Panduan lengkap budidaya ikan lele. Staff redaksi. https://alamtani.com/budidaya-ikan-lele/ diakses tgl 16 September 2020 jam 12.26 WIB

Anonim. 2009. Tiap hari, 12 ton lele dikonsumsi. http://www.waspada.co.id/ index.php?option $=$ com_content $\&$ view $=\mathrm{a}$ rticle\&id=35410:tiap-hari-12-ton-leledikonsumsi\&catid $=95 \&$ Itemid $=146$

2020a. Budidaya Azolla untuk Pakan Ikan Lele dan Nila. Diakses dari https://bibitazolla.com/bibit-azolla-untukpakan-ikan/

, 2020b. Manfaat Rumput Azolla Pada Budidaya Lele. Diakses dari https://www.sangkutifarm.com/manfaatrumput-azolla-pada-budidaya-lele/ , 2020c. Azolla Penghasil Lele Organik Kualitas Ekspor Nutrisi Terjamin. Diakses dari https://ulyadays.com/leleorganik/

Khan, M, 1988. Azolla Agronomy. UPLB. Phillipine.Anonim. (2009). Tiap hari, 12 ton lele dikonsumsi.

Sudadi, S. (2017). Keterpaduan Antara Beternak Puyuh, Lele Dan Azolla Dalam Mengatasi Limbah Puyuh Dan Mahalnya Pakan Lele. PRIMA: Journal of Community Empowering and Services, 1(1), 11. https://doi.org/10.20961/prima.v1i1.35148

Sudadi, \& Suryono. (2016). Pemanfaatan azolla sebagai sumber pakan pada budidaya sistem ganda azolla - lele. Caraka Tani, 31(2), 114-117.

Suwarto, S. (2017). Pemanfaatan Limbah Bulu Ayam Potong Sebagai Pelet Pakan Lele Untuk Menekan Biaya Produksi Beternak Lele. PRIMA: Journal of Community Empowering and Services, 1(1), 22. https://doi.org/10.20961/prima.v1i1.35150 